\title{
Ethnographing flows, (re)thinking categories
}

\author{
Andréa Lobo' \\ Igor José de Renó Machado² \\ 'Universidade de Brasília, DF, Brasil \\ ${ }^{2}$ Universidade Federal de São Carlos, SP, Brasil
}

\begin{abstract}
In this article we explore universes of circulations, flows and mobilities along two interconnected axes. We propose a reflection on the dynamics of managing bodies and populations in transit through categories that regulate journeys and stays, and produce (mal)adaptations. In complementary form, we also question the classificatory processes that pervade the experiences of migrants when they enter distinct regimes of producing difference and are racialized, ethnicized and generified. Our hypothesis is that the connection between these two axes involves the production, at diverse levels, of 'out of place' bodies.
\end{abstract}

Key words: Mobilities; migrations; race; borders; anthropology.

\section{Etnografando fluxos, (re)pensando categorias}

\section{Resumo}

O objetivo do artigo é abordar universos de circulações, fluxos e mobilidades a partir de dois eixos interligados. Por um lado, propomos uma reflexão sobre as dinâmicas de gerenciamento dos corpos e populações em trânsito por meio de categorias que regulam passagens e estadias e produzem (in)adequações. Complementarmente, questionamos os processos classificatórios que perpassam as experiências dos migrantes quando adentram distintos regimes de produção da diferença e são racializados, etnicizados e generificados. Nossa hipótese é a de que a conexão entre os dois eixos abordados se dá pela produção, em diversos níveis, de corpos "fora de lugar". Palavras-chave: Mobilidades; migrações; raça; fronteiras; antropologia. 


\section{Ethnographing flows, (re)thinking categories}

Andréa Lobo

Igor José de Renó Machado

Circulations, flows and mobilities constitute an important part of the debates in contemporary social sciences. The approaches taken to the connections between diverse social fields at global level have the potential to renew our conceptions about culture and society and, more recently, about bodies, places and their interactions. This Vibrant dossier discusses universes in which people circulate, exploring two essential and interconnected aspects: (1) the management of bodies and populations in transit through categories that regulate journeys and stays, and produce (mal)adaptations; (2) the classificatory processes that pervade the experiences of migrants when they enter distinct regimes of production of difference and are racialized, ethnicized and generified. What connects the two axes approached in the articles making up the dossier seems to be the production, at diverse levels, of 'out of place' bodies.

As Lobo, Motta and Trajano Filho (2014) argue, the notion of 'out of place' (or away from home) only makes sense in opposition to a place of origin, one that is mine, a place to which I belong. It thus contains the notion of movement that leads persons, images and places to shift place. But a place out of place also demands a new comprehension of the concept of place, an understanding that relatives the spatial and geographic matrices of the term and adds to it something from the communicative fields (Trajano Filho 2010). Thinking about 'out of place' people, therefore, also forces us to think about the subtleties and complexities produced by the reciprocal and mutually constitutive interactions between identification and categorization and between self-image and the image constructed by others, themes explored by the articles constituting the dossier and that reveal the new approaches to flows and circulations.

There is also another dimension that complements the axes highlighted above. We refer to borders as producers of belongings and their distinct systems of meanings that end up producing subjects who 'are from here' in contrast to those 'outside.' It is productive to explore the conception of both places and borders as social fields - that is, imagined networks that shape belongings or distancings - and not as units circumscribed to spaces delimited or fixed in a geographic territory. Going beyond places and their points of transit as geographic spaces can help us to explain better ethnographic contexts marked by fluidity and mobility. Furthermore, this perspective allows us to reflect on the regimes of truth that end up reproducing technologies of managing the other that fix the latter in excluding categories and as vulnerabilized subjects.

\section{Flows, borders and categorizations}

The way in which the social sciences have dealt with the relationship between movement and borders reveals the reproduction of a certain dichotomous thought, emphasizing either the fixing of boundaries or the circulation of people, things and symbols. A key factor is that who draws these borders and defines their porosity is the State. Likewise, it is the latter that structures the relations between its institutions and the subjects in mobility, defining how they will be received, their status, facilitating their passage or hindering their stay, as Drotbohm and Winters explore in this dossier. This structure widely defines the everyday life of these subjects, the rights that they can obtain, and their level of participation in economic and social life. 
As Feldman-Bianco et al. (2020) emphasize, although mobility has always been a feature of societies, the circulation of people globally became part of the formation of capital during the era of the Great Navigations and subsequently with the formation of the nation state. Hence, it both fed and was fomented by colonialism and by the later capitalist expansion with its structures of domination, inequalities, alterities and racialization of the other, whether internal (indigenous or black populations) or external (migrants, refugees, foreigners) (2020: 03).

It was during this process that the State acquired a monopoly over the control and surveillance of people entering, circulating and leaving its borders. Yet not only this. Beyond the 'spectacle of borders'(De Genova 2020), there is an entire bureaucratic apparatus that encompasses legislation, politics and regimes of identification that recognize national citizens and exclude non-nationals, exerting different forms of management over the latter (see the article by Angela Facundo Navia in this dossier and Feldman-Bianco et al. 2020, Hamid 2012, De Genova 2020).

It is in this sense that the production of the illegality of determined categories of persons is not only performed by the surveillance undertaken on state borders, the legitimate locus of exclusion, it is also constantly reinforced by surveillance policies that strengthen and extend their control. As Sayad (1998) wrote, this apparatus acts as a constant reminder of the temporary, illegal and out of place condition of some people, but also of the versatility of those mobilities that are 'irregular' or 'unauthorized' and constitutive of the global system: after all, while the States possess their technologies for controlling mobilities, these policies generally produce contrary effects. As various of the following articles show, the border spectacle, which is presented as a scenario of exclusion, is revealed by extension as an initial point of a process of subordinate inclusion (De Genova 2013).

What this entire apparatus produces is continuity in time and space, a condition of disposability of the labour of migrants, refugees and others. But it also cruelly reveals the disposability of human life. As De Genova argues:

Entire categories of persons are simply treated as superfluous and, although their illegalizable (and thus 'cheap' and malleable) labour is evidently in high demand and is certainly desirable among many employers, their (racialized) bodies, their personas, their lives and the broader communities in which they participate are stigmatized as 'undesirable' and transformed into virtual 'garbage,' human 'garbage' to simply be discarded (De Genova 2020: 157).

There are two sets of questions that, in our view, follow on from this picture and that implicate us as social scientists. First, how do we challenge the apparent naturalness of categories that subalternize the other when we elaborate analyses about these realities? The care needed here is to avoid reproducing these schemas of oppression, but to elaborate alternatives to these. This takes us to the second aspect: can we construct other possible social worlds?

Thinking about vocabulary is fundamental. It was Hannerz (1997) who, at the end of the 199os, questioning the place of globalization in the history of anthropological ideas, expressed concerns about the set of terms intended as concepts, in distinct degrees and intensities - that is, the categories that aim to become analytic tools to think about modernity with its intrinsic characteristics. Terms like flows, limits, a 'world in creolization,' and hybrids compose this vocabulary that spans the twentieth century and that connects continents. For the author, the end of the 199os was the period when profound changes occurred in the anthropological discipline. Following on from the strong contrast made between stability and movement, studies have focused on the urgency of capturing action, relations and change. More recently we can observe the reconstruction of the place of the other and the need (justified by the 'transformations of the world') to account for flows, large-scale social phenomena, multiple actors, interconnections and diverse subjects (Lobo 2012). 
In this process, social categories have become important tools for producing the place of the other and their transfer to the analytic field must be undertaken in a critical manner. The distinction between the administrative, discursive and analytic levels is an imponderable, given that we know that the States, in diverse ways, shape the forms through which people speak of migrations and mobilities. Taking, for example, the category of refugee in the Brazilian public debate today, we can observe that initially the term is approached pragmatically: in other words, it involves an administrative category, technically purified and limited to a semantic issue. But when we pass to the discursive level, taking the media as an example, we can observe the construction of narratives that label refugees as a danger and a threat, and, on the other hand, Brazil as a cordial country that nonetheless takes them in (Machado 2020).

Hence, the refugee condition is produced as an effect of the law, but is also maintained as an effect of discursive formation, just like the 'illegality' of migrant subjects, for instance. When we turn to the analytic level, we need to challenge the apparent naturalness of these categories and the forms through which the sociospatial premises and conceptions of nationalism significantly shape the conceptualization of the circulations themselves. It becomes necessary to expose how determined notions serve to conceal, discriminate, favour or hide an entire class of subjects and produce a place of 'disposable humans.'

When we transfer such categories to the field of concepts, it is vitally important for us to be wary: we need to ensure that we are not complicit with the techniques of exclusion that produce illegal and 'racialized' migrants or refugees by giving them an aura of 'naturalness,' averting the reproduction of this condition in other areas of social life when other orders of classification of these others are at work. As the papers in the second part of this dossier reveal, circulation emerges in diverse ethnographic situations as a racialized issue centred on bodies. As a consequence, the classificatory systems offered by the state (illegal, undocumented, immigrant, refugee, and so on) and expanded on by the media show feed the production of racialized and 'out of place' bodies, as well as racialized and racializable places of exclusion (see the articles by Gonçalves and Luna Sales).

Nicholas De Genova proposes one possible path for anthropologists, which involves taking on the challenge of delineating the historical specificities of contemporary mobilities and the processes of circumscribing them in the legal and political economies of particular States. As the author argues, it is only by reflecting on the effects of the social, legal and historical contexts in our research that we can elaborate a critical anthropological prospectus that is not complicit with the naturalization of illegalities and the consequent racializations of subjects in mobility. "What at first seemed to be a merely terminological question, therefore, after more careful consideration, turns out to be a central epistemological and conceptual problem with significant methodological ramifications, ethical implications and political repercussions" (De Genova 2002: 423).

Other paths, complementary to De Genova's approach, have included the analytic construction of another possible world, one not only critical of existing ordering processes but discerns new forms of relating in a world that is ultimately borderless, in which the opposition between place and out of place can become diluted. We provide two examples that, via distinct paths, challenge us to imagine.

Before the turn of the century, Clifford (1997) proposed exploring and extrapolating the different possibilities of people's movements by leaving aside the perspective of migratory studies and working with other possibilities of flows, incorporating them into the analyses. Pursuing his endeavour to expand the field of vision, the author proposes a new conception of place as relation. When Clifford challenges us to think about place as an itinerary, he proposes more than just moving from studies on cultures as limited and self-contained to a new vision that incorporates flows and movements. He argues that we need to see cultures as phenomena constituted by flows, a new perception of the social world, seen less as a localized habitation and more as a series of encounters. Along these lines, he proposes the term 'travel' as an alternative and expansive concept that encompasses diverse experiences - diasporas, borders, migration, refugees, tourism, pilgrimages, exile. 
By inverting the formula, the author inverts the question. If travel is the norm, then it is habitation that requires explanation. After all, in some societies, as in the diasporas, for instance, the question that makes sense is not why people leave but why other people stay at home. To be clear, this analytic perspective does not argue that localities do not exist or that everyone is travelling, is cosmopolitan or deterritorialized: it is not a nomadology (Clifford 1997). What can be retained here is the possibility he poses of a conceptual approach to everyday histories, tactics and practices of inhabiting and travelling that are not captured by social worldviews in which the local is the norm and the movement of some subjects is not just the exception but something that produces vulnerability and exclusion.

Recently, Achille Mbembe has reflected on these same questions but from other directions. In an article titled "The idea of a borderless world" (2018) the author reframes the question to show that the power of borders not only restricts movements and intensifies the vulnerability of stigmatized groups and those more racially marked, it also regulates the distribution of populations over the body of the earth. In other words, his argument goes beyond the control of bodies to include the control of movement itself.

He proposes to investigate the possibilities for recreating the utopia of a borderless world. Ultimately, it is this notion that lies at the base of western conceptualizations that attempt to explain the tensions between the local and the global since the end of the twentieth century, such as the concepts of transnationalism and cosmopolitanism. However, he moves away from such perspectives (including Clifford's) and their propositions of a cosmopolitanism under the sign of neoliberal individualism, anchored in four freedoms of movement: of capital, goods, services, and people. In relation to these, depending on the nationality of your passport, the world indeed belongs to you. But this is not the case of most human beings inhabiting the earth (Mbembe 2018).

It is, therefore, on people's supposed freedom to come and go that Mbembe's proposition focuses: it must be extended to the planet's poor. Based on what he calls the African model (in contrast to the individualist model), the author recuperates the notion of the border in terms of its basic function - to be traversed - and advocates a world without visas.

One could just get on a plane, a train, a boat, on the road, or on a bike. Rights of non-discrimination would be extended to all. I will give you one little example. In Cameroon, until the beginning of the 1980 s, it was possible to travel to France with one's national identity card. Most people went to France and came back. They did not go because they wanted to settle there. Most people want to live where they 'belong.' But they want to be able to come and go. And they are more likely to come and go when the borders are not hermetically closed. So, a borderless world imagined by the fourth freedom of movement is premised, therefore, on this right of non-discrimination and on this circulatory and pendular set of migrations (Mbembe 2018). ${ }^{*}$

Mbembe makes clear that a borderless world is a utopian intention. Indeed, the very concept of utopia relates to the borderless, like the imagination, for example. And what problem is there in using the recourse of utopia to think about social realities? If it is a problem from the economic and political point of view, it can be a powerful resource for us to free ourselves from the "atrophy of an utopian imagination" fomented by perspectives that nourish narratives of separation rather than a politics of humanity (Mbembe 2018). Between the dystopia of the current world, in which the sacrifice of many lives improves the life of the few, we need utopias more than ever.

1 https://africasacountry.com/2018/11/the-idea-of-a-borderless-world, accessed 01/10/2020, no pages. 


\section{The dossier in parts}

The articles united here contain an interesting diversity of ethnographic setting and approaches that evince the usefulness of approaching circulations and mobilities less as a trait inherent to determined social contexts and more as aspects that intersect social relations transversally. The thematic focus of the pages that follow is on the diverse movements of people and on the processes of resignification that accompany this movement; on the transit of information, ideas, symbols and values; and on the dynamics of cultural mediation and the arising classificatory processes. These fluxes are observed at different scales through discussions capable of incorporating the historical depth of the experiences of circulation and of eliciting a new way of looking at the articulation between these movements and the sociocultural limits of various types.

Flows, circulation and movement have become commonplace terms in discussions of the contemporary world, revealing a relative saturation of the arguments and debates surrounding these categories. Nevertheless, there remains much for us to comprehend about the social, political, economic and cultural processes analysed through the prism of flows in contemporary life. In this sense, empirical research becomes ever more necessary to complexify the debate and avoid 'rushed responses.' As expressed in the following articles, ethnographic research is a key tool for attaining this aim.

\section{Categories, people and State}

The text by Heike Drotbohm and Nanneke Winters advances a comparative proposal that takes the setting of intra-American movements as a parameter to think about the production of volatile categories involved in managing the migratory flow. The humanitarian visa in Brazil and the permisso de ingresso y tránsito (entry and transit permit) in Costa Rica are examples of categories mobilized in exceptional situations that momentarily facilitate the migratory flow for specific populations but do not produce long-term integration.

In Central America, these travel permits are explicitly categories of movement: they enable journeying, not staying. But the humanitarian visa can also take the guise of "categories of transit," as Machado (2020) points out. Drotbohm and Winters's text presents a proposal for analysing these emergences and their implication in the production of categories that end up generating more movement rather than integration. On the other hand, the scenario of large movements that cross the Americas heading towards the United States offers in itself a supranational framework for reflecting on categories of contemporary migratory movement and regulation, as well as the flows of Syrian refugees traversing Europe towards Germany (Holmes \& Castañeda 2016).

We can think of the categories that structure the management of the flow of Venezuelans in Brazil from Drotbohm and Winters's perspective: according to the text presented by Angela Facundo Navia, the situation of Venezuelans 'interiorized' in Caicó (Rio Grande do Norte, Brazil) through the Acolhida Program is extremely fluid. Various categories were mobilized to manage the Venezuelans who arrived from across the border between Roraima (Brazil) and Venezuela: requests for refugee status, extension of the Mercosur agreement on migration, radical changes in the policy of granting refugee status, and so on. Here we find ourselves in the middle of new successive 'happenings.' The hosting operation itself, organized by military forces in Roraima, is a new form of policy tested since the Temer government (Machado \& Vasconcelos 2018). Navia, though, presents us with an ethnography about another point of the Acolhida Program, no longer involving the military, since reception of these 'interiorized' people is outsourced to civil society organizations, primarily religious entities.

In this process, the author offers us a complex panorama that involves the inflexibility of the categories of 'family' on the part of the hosting organizations, which ends up limiting the possibility of families (in the configuration in which they are presented by the producers of these categories) to remain together. 
Navia spotlights the question of the variability in the documented status of people within the same family group and how this entails different bureaucratic forms of relating to the public authorities. Finally, she contrasts the hosting operation with the process of voluntary resettlement for Colombian refugees that took place in Brazil at the start of the twenty-first century (Navia 2019).

This scenario can be understood as one of the contemporary characteristics in the management of immigration in Brazil, highlighting the political question as a pivotal factor in the choice of potential privileged beneficiaries. In the case of the Venezuelans, the collective concession of more than 38 ,ooo refugee statuses as of 2020 allows us to perceive a radical and clearly preferential change. At the same time, the question of the humanitarian visa, which was inserted in the new Brazilian migration law, was demonstrably restricted by the regulation of the law itself (Machado 2020). Thus, momentary facilitations are produced while other obstacles are created: this scenario is thus a jigsaw puzzle whose outcome is the specific preference for some immigrants over others. And at the moment, this Brazilian constellation of regulations is clearly marked by a racialization of the approach to migration: Haitians and African immigrants/refugees are overlooked in the processes for facilitating legalization (Machado \& Pardue 2020, Silva Jarochinski \& Alves 2017).

\section{Bodies and (in) flows}

Menara Guizardi's text is concerned with understanding the relations between the gender hierarchies established by care practices and crossborder movements in the region of the triple frontier (Brazil-ArgentinaParaguay). Here we have socioeconomic orderings established by distinct state regimes and women who seek for alternative ways for distributing care to family members, looking for support from public healthcare networks and also from religious and family networks. The author explores the dynamics of producing excess of work among women living on the border, contributing to our understanding of the relation between gender hierarchies and attribution of the carer role, which falls on women's shoulders in situations of work overload in their families.

The search for care to be received in specific situations - during pregnancy, medical care for a disabled child, medical treatment for undiagnosed diseases - produces a constant crossborder movement, attempting to assuage the excessive workload that gender inequalities instilled in their lives in one of the three countries of the triple frontier. The author develops the idea of a 'care-o-meter' as an intellectual mechanism for understanding this search to share the care workload with other family members.

The text by José Hildo de Oliveira Filho presents us with a little-known situation of mobility, linked to the professional practice of football (outdoor and indoor) in leagues in Central and Eastern Europe. While in Menara's text the discussion revolves around the idea of 'care' and its gentrification, here the author shows how care and fear of injury are decisive factors in the construction of careers in these peripheral leagues, since very often athletes are unable to receive care from their clubs. The author emphasizes what he calls the 'essential sadness' in the migratory experience, drawing support from the expression of Said (1995), given that these experiences are marked by isolation from their own family, fear of injury, conflictual relations with the clubs, and very different life circumstances.

Oliveira Filho's text, like Bernardo Fonseca Machado's, seeks to reflect on the migratory phenomenon through specific networks of migration supported by professional specificities (soccer players and actors). This makes evident a new approach to apprehending people's movements where a concern with the diversity of flows acquires greater analytic density: fewer texts on 'Brazilian migration' and more texts on 'Brazilian players, 'Brazilian actors.' 
A comparison of the texts by Oliveira Filho and Machado proves interesting. In both the focus on specialized migrations of football players and actors enables us to reflect on a contrast between the imaginations of the body and the construction of ideas about the 'nature' of being Brazilian. In Machado's text, we see how Brazilians (generally middle class) attempting to enter show business in the United States as actors in theatre, musicals, TV and cinema, end up feeling for themselves the effects of US constructions of difference: their body is read as a 'Latin' body, which for many of them is shocking. Between rejecting and accepting the stereotype, immigrants attempt to dialogue with these US constructs. But there is little escape beyond coping with the US representations of a Latin body. For their part, they construct images of themselves as 'emotionally' Brazilian, appealing to the supposedly innate emotion of the Brazilian as an advantage when acting.

There is, therefore, a naturalization of Brazilian emotion, which functions as a counterpoint to the construction of the Latin body by their employers. Some discover the elasticity of this 'Latin' body since they may perform roles playing everything from Italians to Middle Eastern people in general. But these US stereotypes construct separate meanings for the sexes: women more quickly gain roles playing 'fatal' and sensual characters (matching the imaginary surrounding Latinos in the United States) while men have many more problems in finding roles. In the case of football, the opposite occurs, since the body of the Brazilian man is conventionally accepted as appropriate for the sport and encounters diverse markets for work (although more and more women players are also finding a place in foreign markets).

Machado's work allows us to think about symbolic orders of representation of the other and, at the same time, the forms in which these 'others' deal with these processes: crises, acceptance, 'tactical' adaptation, refusal. We can see a series of possibilities, including a movement of reaffirmation of certain cultural specificities not fully recognized by employers, but fundamental to Brazilians being able to confront this machine of representation that, in many ways, they feel to be oppressive. Meanwhile, the Brazilian soccer players abroad use Brazil's fame as a footballing nation as a form of accessing markets around the world, opened up precisely by a similar kind of imaginary of the other. It is worth highlighting the inversion that the images produce in the United States: women can more readily access certain roles, which results in another relation between gender and migration, different to the kind analysed by Guizardi in her paper.

Camila Daniel develops research in which she inverts the contexts explored by Machado and Oliveira Filho, since the migration involved is not Brazilians abroad but Peruvians in Brazil, specifically in Rio de Janeiro. However, the question of stereotypes and representations of the body are fundamental here too, examined from the viewpoint of what the author calls 'racialization.' These Peruvian bodies can destabilize racial conventions in middle class spaces in Rio de Janeiro, the author argues. She provides a highly productive discussion on the relationship between bodies that display more characteristics of cholas (a term that Brazilians translate as indios, Amerindians) and those that can pass as white bodies in Brazil.

Like the Brazilians in the United States discussed in Machado's article, nationality in itself can produce a racialization, and even a 'white' body, if Peruvian, can be read as indigenous. The author emphasizes that in these cases it is still possible to 'hide nationality' and, therefore, occupy spaces as a white person. But this is no longer possible when the Peruvian woman or man carries bodily features that Brazilians associate with indios, in a generic and stereotyped reading. It is not for nothing that one of her female interlocutors says that she discovered she was india only in Brazil. Daniel, attentive to the racial hierarchies both among Peruvians and between Brazilians and Peruvians (as well as among Peruvian immigrants in the United States and she herself), produces an important discussion on processes of racialization and migration, which point in many directions, two of which she highlights: the discriminatory processes experienced during migration, and the effects of this lived experience on the forms of racial/cultural definition of themselves, which become transformed after this migratory experience. 
Camila Daniel also skilfully explores her theme in the way that she deals auto-ethnographically with the effects caused by her own black body, leading to situations that emphasize both experiences of racism (among Peruvians in Baltimore, USA) and the stimulation of a discussion on Peruvian racism against Afro-Peruvians (when she is asked to read a poem on the topic at Peruvian cultural events in Rio de Janeiro). As 'bodies on the margin,' in a perspective influenced by the work of Grosfoguel (2016), both Daniel and the Peruvians develop processes of critical reflection on the racialized experience of living in Brazil, contributing powerful viewpoints to the debate on migratory studies.

Vinícius Ferreira proposes a discussion on the category of 'diaspora,' but in a completely different context: Indian academics in institutional places of 'global' academia in the United Kingdom, the United States and other English-speaking countries (or in institutions of these countries in other places of the world). The question that calls our attention is the journey that leads to the author to perceive the term diaspora as one to be avoided by these academics, precisely because it is linked to 'unglamorous' types of migration that is, migration for definitive settlement in these countries by people from less wealthy classes or castes. The self-definition of these academics as 'global citizens' involves two aspects: a privileged caste and class situation, which enables access to the main educational institutions of India and later abroad, and the idea of 'circulation.' In contrast to immigrants, they can move away at any moment in search of new academic horizons, other invitations, and so on.

Thus, circulation is a privilege constituted in opposition to the lower mobility of 'normal' immigrants. The global Indian citizen does not identify with the migrant communities from his or her country, nor apparently construct sociabilities among them. This process narratives a cosmopolitanism typical of Hannerz (1997), detached from the proximity of very pronounced local cultures. But in analysing this perspective, we should consider its status as a self-narration marked by cosmopolitan values and, to some extent, as a narrative that valorizes the trajectory itself. It is interesting to compare this process with those described by Daniel and Machado, where there is a centrality of the body in the migratory experience of Peruvians and Brazilians: the body is the place where prejudice and stereotypes are sedimented. In the narratives collected by Ferreira, it is precisely the body that vanishes. We do not know whether this was just an outcome of the different themes focused on by the authors concerned, or whether it is effectively a subject rendered invisible in the narratives of global Indian academics. In any event, it is interesting that in a text that deals with their identifications as subjects, the body does not appear as a focal point of reflection.

In fact, the body appears at two moments: when the author writes about the belief common in India that darker skin tones are related to lower castes or the Dalits, while the most privileged populations tend to have lighter skin; and also when a cosmopolitanism woman from a lower caste describes leaving India as a flight from gender oppression (a place to which she has no wish to return). Thus, the body is present in the discussion in India, just not in the experience of the intellectuals themselves: the question we can ask is whether they suffer discrimination and are placed in racially hierarchized places that do not correspond to their cosmopolitan imaginations. Just like the middle-class Peruvians with 'whiter' features, do these Indians feel a prejudice in response to their nationality or even their bodies (like the Peruvians with more indigenous features)? The question to which we seek a response in other texts by Ferreira is whether the cosmopolitan Indian body is a body without materiality: that is, when they walk in the street in England, is this cosmopolitanism maintained? Or does cosmopolitanism only exist in the narrative that disembodies intellectuals from the lived world?

Whatever the case, in the context of the discussion that we can propose among the dossier's texts, the absence of the body and the emergence of a category of 'global citizenship' are perhaps enough for us to think about the processes of producing categories relating to migratory phenomena: from those mutable statuses emphasized by Heike Drotbohm and Nanneke Winters, as well as Facundo Navia, to those produced by migrant subjects. In this latter universe, the body and racial hierarchies acquire prominence even if through their 
absence, as in the case of these Indian academics interviewed by Ferreira. The constitution of migrant realities is permeated by a complex confluence of categories, which counterpose those produced by the immigrants (their own hierarchies, prejudices, and differences) which they encounter in the places of migration and which are put into action by their own presence.

\section{Places and circulations}

Contemporary works on migration tend to be highly varied and Ana Paula Sales's text is a prime example: the object of her study is less migration and more a beach, a locality that has undergone many transformations, some of them informed by the movements of diverse agents. Thus, migration is one of the components of the body-locality that forms the beach of Iracema, in Fortaleza. Telling a history spanning more than a century, the author shows us how the beach was gradually feminized, constituted as a space of bourgeois leisure, later a space of leisure for US military personnel during the Second World War (and their relations with local young women), a decadent place when the Port of Mucuripe was built, which silted up the beach, the space of international tourism that produced relation between gringos and lower class women, a place where 'sexual tourism' was combatted, a place where tourism practically ceased due to the fights against sexual tourism, although a population of gringos still remains.

All these transformations are modulated by a careful form of establishing class distances, expressed in avoiding the production and flow of non-white bodies in the context of Fortaleza's elite. Thus, the evident mixture produced by gringo tourism in search of love or sex was combatted as a form of mixing the colours of bodies, as a destabilizing factor in the racial hierarchies constituted since the past century. Thinking about the beach, therefore, inevitably means thinking about the bodies that occupy it, about the hierarchies that traverse them, and about the mobilities that shape it. The profusion of classifications produced over this lengthy period of time analysed by the author (more than 100 years) always revolve around bodies, racializations and hierarchies of alterity. As in the various texts on flows discussed above, circulation is also a racialized question, centred on bodies, producing localities.

The circulation of persons and the production of places and memory is also the theme of the text by Renata Sá Gonçalves, who seeks to understand the meanings in dispute behind the organization of historical tours through the region known as 'Little Africa' in Rio de Janeiro's port zone. Centred on the discovery of Valongo Wharf - the largest slave port in the Americas - groups of activists and academics try to produce a critical memory of slavery and its effects on Rio de Janeiro. One of the strategies is the elaboration of tours through the area that contains, 'under the feet,' something of this memory. These tours are intersected by memories, public entities and also cultural practices linked to black music in Rio de Janeiro.

The text makes evident the historical configuration of a central place in the vast network of the slave trade in the eighteenth and nineteenth centuries. To think about the effects of these brutal journeys on Brazilian history, groups today attempt to appropriate spaces of the city through these guided tours. At the same time, the 'global' processes of gentrification that were set in motion with the major sports events of the World Cup and the Olympics in Rio de Janeiro generate tensions between the population living in the port area and the land development and political intentions of these processes. In the middle of this situation, the discovery of the Valongo Wharf forced public recognition of the memory of slavery, generating the opportunity for these claims to take form in Rio de Janeiro's urban tourism.

Between the old port zone and its urban effects, in some ways seen too in the construction of the Port of Mucuripe in Fortaleza described by Sales, we find a scenario of constituting places full of meaning. But these places are also filled by people who circulate, who walk about, who occupy and who live. 
These bodies are also part of these places and Little Africa tells us about the tensions that involve the black body, or the imagining of the black body by the critical memory of slavery. Walking through the city on these routes of negritude also means constructing a black body, a process that tensions gentrifying interests (which, in general, tend to expel 'non-hegemonic' bodies from places traditionally occupied by them).

\section{Final considerations}

This dossier centres its attentions, at diverse levels, on the question of racialization and the production of 'out of place' bodies: either out of place because they have migrated and find themselves subject to classifications in the places of arrival, or because the local hierarchies already place them, historically, outside of what is presumed as normality (in this case, the circulation of these 'out of place bodies' through places in the city also produces 'racialized/racializable places' of exclusion). In the case of Sales, non-white female bodies challenge a bourgeois order and set processes of exclusion in motion. These movements may even be associated with entire urban areas that are 'removed' from the space of circulation of the elite, as in the case of Iracema beach (or that are, on the other hand, taken back from undesirable bodies through processes of gentrification [Lees 2016]). On the other hand, the urban circulations described by Gonçalves allude to the construction of a memory of slavery (and the black body) that imposes some resistance to the processes of gentrification that overall signify the 'whitening' of these regions and the expulsion of non-white bodies.

Another fundamental dimension is the question of the categories mobilized, created or deleted in migratory processes. As Drotbohm and Winters emphasize, the incessant production of categories for managing migration may have an excluding effect, even when they are created to, supposedly, facilitate the life of immigrants. Navia also shows us another facet of the same process, when the management of migrant collectives (in this case, of Venezuelans), is traversed by so many migratory categories that people in the same family may face distinct legal situations, hindering the construction of processes of 'integration.'

Categories, on the other hand, are also instruments of social classification that pervade the experience of immigrants in any place: how they are classified, how they are racialized, how they are read in their places of migration are all effects of classificatory systems that operate categories created in other racial and social contexts. Brazilians are Latinos in the United States. Peruvians are indios in Brazil. Residents of the triple frontier are classified differently in institutions in the three countries according to distinct classificatory systems of differences. Hierarchies of difference are organized around the migratory experience, even for those who aim to escape them as 'global citizens.'

Connecting these aspects is the objective of the articles that follow. What connects the different approaches is the perception that while places, cities and towns are everywhere, networks, intersections, roads and crossings distribute the movement between places, connecting some with others and, in doing so (re)produce subjects and localities. Thus, it is the contemporary world, the circulation of persons between borders being a fact of reality. The question that we leave here is, what do we do about this? Either we continue to produce illegal migrants and imprisonments, especially of those from racialized/racializable populations, or we challenge ourselves to think (and to work towards building) a world in which one can circulate freely and in which everyone has the right to come, go and live. What is your option? 
Received: November 25, 2020

Approved: November 26, 2020

Translated by David Rodgers

\section{Bibliography}

CLIFFORD, James. 1997. “Travelling Cultures”. In: Routes. Travel and translation in the late twentieth century.

Cambridge (Mass.): Harvard University Press. pp. 17-46.

DE GENOVA, Nicholas. 2002. "Migrant 'Illegality' and Deportability in Everyday Life". Annual Review of

Anthropology, 31: 419-447.

. 2013. 'Spectacles of Migrant 'Illegality': The Scene of Exclusion, the Obscene of Inclusion'. Ethnic and Racial Studies, 36(7): 1180-1198.

2020. "O poder da deportação". REMHU, Rev. Interdiscip. Mobil. Hum., 28(59): 151-160.

FEDMAN-BIANCO, Bela; SANJURJO, Liliana \& DA SILVA, Douglas. 2020. "Migrações e deslocamentos:

balanço bibliográfico da produção antropológica brasileira entre 1940 e 2018”. BIB, 93: 1-58.

GROSFOGUEL, Ramón. 2016. "Del 'extravismo económico' al 'extravismo epistémico' y al 'extravismo

ontológico': una forma destructiva de conocer, ser y estar en el mundo". Tabula Rasa, 24: 123-43.

HAMID, Sônia C. 2012. (Des)Integrando refugiados: os processos do reassentamento de palestinos no Brasil. Tese de Doutorado, PPGAS/UnB, Brasília.

HANNERZ, Ulf. 1997. "Fluxos, fronteiras, híbridos: palavras-chave da antropologia transnacional". Mana, 3(1): 7-39.

HOLMES, Seth M.; CASTAÑEDA, Heide. 2016. "Representing the 'European refugee crisis' in Germany and beyond: Deservingness and difference, life and death”. American Ethnologist, 43(1): 12-24.

LEES, Loretta. 2016. “Gentrification, race, and ethnicity: towards a global research agenda?”

City \& Community, 15(3): 208-14.

LOBO, Andréa. 2012. Entre Fluxos. Brasília: EdUnB.

LOBO, Andréa; MOTTA, Antonio; TRAJANO FILHO, Wilson. 2014. África fora de casa. Imagens for a de lugar. Recife: Editora Universitária.

MACHADO, I. J. R. 2020. "Purity and mixture in the category of refuge in Brazil". Journal of Immigrant and Refugee Studies, 1:1-13.

MACHADO, I. J. R.; VASCONCELOS, Iana Silva. 2018. "Desejáveis e indesejáveis: controvérsias no acolhimento de venezuelanos/as em Boa Vista: RR”. Paper presented at 31ㄹ Reunião da ABA, Brasilia, 18p. Mimeo.

MACHADO, I. J. R.; PARDUE, Derek. 2020. "Migrant refugee spatialities lived and legislated in São Paulo". In: Living (Il) legalities in Brazil. London: Routledge. pp. 36-51.

MBEMBE, Achille. 2018. "The idea of a borderless world”. Africa is a Country. Politics. https://africasacountry. com/2018/11/the-idea-of-a-borderless-world. Accessed 01/10/2020.

NAVIA, Angela Mercedes Facundo. 2019. "Deslocamento Forçado na Colômbia e Políticas de Refúgio no Brasil: Gestão de populações em êxodo." Revista de Estudos e Pesquisas sobre as Américas, 13: 245-267. 
SAID, Edward W. 1995. Cultura e imperialismo. São Paulo: Companhia das Letras.

SAYAD, Abdelmalek. 1998. A Imigração ou os paradoxos da alteridade. São Paulo: Edusp.

SILVA JAROCHINSKI, João Carlos; ALVES, Laís Azeredo. 2017. “Categorização, exclusão e criminalização das migrações international migrations". Revista Interdisciplinar de Direitos Humanos, 5(1): 111-26.

TRAJANO FILHO, Wilson. 2010. "Introdução" In: Wilson Trajano Filho (ed.), Lugares, Pessoas e Grupos: as lógicas do pertencimento em perspectiva internacional. Brasilia: Athalaia/ABA. pp. o7-26.

\section{Andréa Lobo}

University of Brasília, UnB

https://orcid.org/oooo-0001-7525-1953

Email: alobo@unb.br

Igor José de Renó Machado

Federal University of São Carlos, UFSCar

https://orcid.org/oooo-0001-7811-2641

Email: igor@ufscar.br 